\title{
Comment: Getting the Methodology Wrong for Analysing the Hydrological Changes in Watersheds
}

\author{
Nitin Bassi ${ }^{1}$, B.K. Harish Kumara ${ }^{2}$, Meera Sahasranaman ${ }^{3}$, Arijit Ganguly ${ }^{3}$ \\ ${ }^{1}$ Institute for Resource Analysis and Policy, Liaison Office, Delhi-110085, India \\ $5 \quad{ }^{2}$ Center for Education Environment and Community, Hassan-573130, Karnataka, India \\ ${ }^{3}$ Institute for Resource Analysis and Policy, Head Office, Hyderabad-500082, India \\ Correspondence to: Nitin Bassi (nitinbassi@irapindia.org)
}

\begin{abstract}
This article is a critique on the paper 'Spatial characterization of long-term hydrological change in the Arkavathy watershed adjacent to Bangalore, India', by Penny et al. (2018), published in the journal of Hydrology and Earth System

10 Sciences (volu me 22, issue number 1). The article highlights choice of inappropriate methodology and faulty assumptions by the authors for analysing the watershed scale hydrological changes, generating misleading results and inferences.
\end{abstract}

\section{Introduction}

Globally there is an increase in demand for water, more so in countries located in semi-arid to arid regions. In India, which is largely semi-arid, many large river basins such as Krishna, Cauvery and Pennar are on the verge of closure or are already closed, with no discharge into the natural sinks (oceans) in low rainfall years. In order to manage water in such basins, it is important to first identify the factors causing growth in demand for water and also the long-term changes and in water supply from catchments and aquifers (runoff and groundwater). The long-term changes in runoff can mainly be because of rainfall change, land use changes (leading to increased evapo-transpirative demand causing reduction in runoff generation), and groundwater intensive use in areas where aquifer discharge contributes to runoff in the form of base flows. Changes in groundwater availability from natural recharge can be caused by changes in infiltration of water from precipitation and natural discharge from aquifers. Apart from understanding the aggregate level changes, it is also important to analyse the spatial patterns, especially in the upstream and downstream parts of the basin as most of the time it is the people in the la tter that get affected by the hydrological changes occurring upstream.

One such attempt to explain spatial pattern of long-term hydrological changes has been made by Penny et al. (2018) in a watershed named Arkavathy in Cauvery river basin. The watershed lies in the state of Karnataka. The study claims to have used a methodology which is appropriate for ungauged catchments. Though the authors have noble ideas, the study methodology, assumptions, results and inferences all have serious shortcomings. Findings based on such shortcomings have limitations when it comes to making useful policy inferences which are discussed in the subsequent sections of the article. 
Hydrol. Earth Syst. Sci. Discuss., https://doi.org/10.5194/hess-2018-187

Manuscript under review for journal Hydrol. Earth Syst. Sci.

Discussion started: 15 May 2018

(c) Author(s) 2018. CC BY 4.0 License.

\section{Misplaced concerns about data unavailability}

A few recent studies that have focused on water management issues in India, have reported lack of time series data sets on hydrology and geo-hydrology and questioned the reliability of data available from official agencies (see for instance, Srinivasan et al., 2015; Penny et al., 2018). Often it is claimed that official agencies are unable to process and manage data properly. In some cases, raw data collected directly from the farmers on scientific phenomena that occurred as long back as 40-45 years, based on recall method, is considered to be more reliable by researchers. While validated data might not be available for free on websites, they are certainly available with the central and state agencies in charge of monitoring surface water flows and groundwater in the basin. The point is one has to make an effort to reach the concerned agencies, collect and interpret the data in the best possible way.

10 Moreover, the situation with regard to hydrological data availability and their reliability has improved remarkably over the past 10-15 years in India. After the World Bank supported Hydrology Project (initiated in 1995), most of the historical data related to meteorology, hydrology, reservoir operations, water quality and groundwater are digitised in many States through establishment of water data centres (WDC). Presently, nine major states in India, including Karnataka where the Arkavathy watershed studied by Penny et al. (2018) falls, have fully operational WDC.

15 Penny et al. (2018) have raised serious concern that official data on surface water flows and groundwater in the watershed were not available and hence justified use of Remote Sensing (RS)/GIS based methodology which they claim is suitable for ungauged catchments. However, as per the basin report by the Ministry of Water Resources, River Development and Ganga Rejuvenation (Government of India, 2014), middle part of Cauvery river basin having an area of about 57,281 sq. km (where Arkavathy watershed falls) has 20 hydrological observations sites, 159 meteorological stations and 612 groundwater

20 observation wells which are maintained by Central agencies alone (Fig. 1). In Arkavathy watershed, there are three stream gauging stations maintained by Central Water Commission (CWC) and about 50 groundwater observations wells maintained by Central Ground Water Board (CGW B). State agencies have more number of observations sites. Therefore, it is not clear which data paucity the authors are referring to.

\section{Selected literature review}

25 The authors (Penny et al., 2018) claim that no attempt has been made in India to analyse hydrological process at the watershed, sub-basin and basin scale and making it appear that their study is perhaps the first such attempt to do so. In the process, they have conveniently ignored a large body of peer-reviewed research work already undertaken not only at the watershed scale (for instance by Garg et al., 2012; James at al., 2015), but also at the basin level (for instance by Gosain et al., 2010; Kumar, 2010). So me of these studies are highly empirical in nature and covered Narmada river basin (Ku mar and

30 Singh, 2001; Kumar et al., 2005; Ku mar 2010; James et al., 2015), Ganga river basin (Anand et al., 2017), Brah maputra and Kosi basins (Gosain et al., 2010). Simply disregarding the existing studies on river basin management, instead of critiquing 
Hydrol. Earth Syst. Sci. Discuss., https://doi.org/10.5194/hess-2018-187

Manuscript under review for journal Hydrol. Earth Syst. Sci.

Discussion started: 15 May 2018

(c) Author(s) 2018. CC BY 4.0 License.

the approach, methodology and findings of those studies if they find them to be lacking in any way, is poor scholarship on the part of the authors.

\section{Wrong unit of analysis}

From the discussions presented in the previous sections, it is clear that there is no dearth of reliable official data on hydro -

5 meteorology and groundwater for Arkavathy watershed and since it is available for a long time period, various agencies are monitoring and managing data well. Strangely, to assess the hydrological changes, Penny et al. (2018) have considered changes in water spread area in the tanks where inflows are not gauged and not the large reservoirs in the watershed of where inflows are gauged, the reason being that reservoirs are actively managed for providing water for urban and agricultural uses. However, the whole purpose of using this approach was to identify changes in tank water extent which can be attributed to

10 changes in tank inflows. Authors have used volumetric water balance equation for estimating the tank inflows (equation 1 on page 600 in Penny et al., 2018).

If the aim of the authors was to analyse the hydrological changes due to changes in land use, the reservoirs which are gauged and for which reliable data on inflows are available would have been a much better choice. A mass balance equation could have been used to estimate the actual inflows based on data on change in storage and outflows at different time intervals as 15 data on rainfall at the reservoir site, releases from the dam, water losses and reservoir water level are available with the water resources department of the state. This data is also available in digitised form with the Karnataka State WDC, which is operated by Water Resources Department, Government of Karnataka for surface water and Groundwater Directorate, Karnataka for groundwater (Table 1).

Thus use of tanks, which are un-gauged, as a unit of analysis has actually adversely affected the confidence level of the

20 model outputs and increased the uncertainty in the results as the tank water spread area may not be an accurate representation of the hydrological alterations happening in the watershed caused by land use changes and other factors, due to the reason that many complex factors (infiltration and evaporation)over and above the inflows affect the water spread area.

\section{Faulty assumptions and inferences}

Some assumptions and inferences in the paper by Penny et al. (2018) are a little hard to comprehend. A few of them are 25 discussed herewith. First, a water balance equation is used to estimate the inflow into the ungauged tanks. For this, it is assumed that the initial storage in the tank is zero. However, the aerial photo provided in the paper shows that there is wat er in the tank before the onset of the first runoff event.

Second, the authors have assumed outflows from the tank to be negligible. This is based on observations on a few tanks and may be true for years with low rainfall. In years with normal and high rainfall, tanks will have overflow which usually enters

30 the downstream tank in cascade, a common occurrence in southern India. In Arkavathy watershed, there is very high interannual variability in rainfall. The rainfall can be as high as $1400 \mathrm{~mm}$ against an average rainfall of about $800 \mathrm{~mm}$ (Fig. 2). 
Hydrol. Earth Syst. Sci. Discuss., https://doi.org/10.5194/hess-2018-187

Third, the authors state that there is no significant spatial variation in rainfall at the watershed scale and for this they seem to have used rain gauging data for several locations. This is false as the average annual rainfall for 15 years (1998-2013) in Arkavathy watershed, using India Meteorological Department (IMD) gridded rainfall data sets, shows significant spatial as well as temporal variation (Fig. 2).

5 Fourth, authors have mentioned that only limited data exists to describe historical declines in the groundwater table. This is also false and as was mentioned earlier, CGWB alone monitors about 50 observations wells in the area comprising Arkavathy watershed.

\section{Poor understanding of groundwater behaviour}

The authors have entrusted full faith in the data collected from farmers to make an assessment on the groundwater levels in

10 the basin. Our contention is that farmers' data might be useful to understand the socio-economic aspects of local groundwater use but certainly not for making in ferences about groundwater behaviour at the local or regional scale. Based on bore well data collected from farmers in a village, Penny et al. (2018) inferred that the groundwater level in Arkavathy watershed is declining. This is a very sweeping inference as groundwater behaviour in hard rock formations (as in Arkavathy watershed) is a complex phenomenon. The water level in dug wells tapping weathered (unconfined) zone might not represent

15 the regional ground water level if the rate of pumping is higher than the rate of recuperation of well. Thus, for the purpose of understanding the groundwater balance due to rainfall and abstraction, the water levels for measurement must essentially be the static water levels (as monitored by CGWB) and not any other dynamic water levels (as encountered in wells which are regularly pumped by farmers).

Contrary to the findings of Penny et al. (2018), the data of observation wells installed by CGWB that monitor groundwater

20 level in the basin indicate that the ground water fluctuation due to draft is positive in a major part of Cauvery middle subbasin where Arkavathy lies. Analysis of long term trend in ground water levels using wells spread across Arkavathy watershed indicate that a higher proportion of observation wells recorded rise in water levels over the 20-year period (Fig. 3). The rising water level trend is likely to be in wells located downstream of urban centres like Bengaluru which receive its wastewater because of negative gradient with respect to surface water bodies. During non-monsoon months, most of the 25 inflows received by stream passing through Indian cities are wastewater. If the quantum of the flow leads to higher hydraulic head in the stream than in the groundwater system, it can result in flow of surface water to the aquifers and thus rise in groundwater levels. Jamwal et al. (2015) estimated that about 600 thousand cubic metres per day of wastewater flows from Bangalore city to Byramangala reservoir (downstream) in Arkavathy basin.

\section{Conclusion}

30 Surface water and groundwater interactions in river basins are quite complex and need good understanding of hydrology (rainfall, runoff) and geo-hydrology (groundwater level trends) and also the hydrological stresses (surface water diversion and groundwater draft) in the basin, to explain the cause-effect linkages scientifically (Kumar, 2010). Attempts using 
Hydrol. Earth Syst. Sci. Discuss., https://doi.org/10.5194/hess-2018-187

Manuscript under review for journal Hydrol. Earth Syst. Sci.

Discussion started: 15 May 2018

(c) Author(s) 2018. CC BY 4.0 License.
Hydrology and

Earth System

Sciences

Discussions

groundwater data collected from farmers and extrapolating it to watershed scale and using RS/GIS processed data without ground truthing will only yield misleading results. Penny et al. (2018) should have exercised more caution by undertaking proper review work, choosing the right methodology, and using scientifically validated data to draw proper inferences about the hydrological dynamics in Arkavathy watershed.

5 Competing interests. The authors declare that they have no conflict of interest.

\section{References}

Anand, J., Devak, M., Gosain, A. K., Khosa, R. and Dhanya, C.: Applicability of ranked Reg ional Climate Models (RCM) to assess the impact of climate change on Ganges: A case study, in: Proceedings of the $19^{\text {th }}$ EGU General Assembly Conference, Vienna, Austria, 23-28 April 2017, 780, available at: http://adsabs.harvard.edu/abs/2017EGUGA..19..780A,

102017.

Central Ground Water Board: Ground water year book of Karnataka state 2015-2016, South Western Region, Bangalore, available at: http://cgwb.gov.in/Regions/GW-year-Books/GW YB-2015-16/GW YB\%20SWR\%202015-16.pdf, 2016

Garg, K. K., Karlberg, L., Barron, J., Wani, S. P. and Rockstrom, J.: Assessing impacts of agricultural water interventions in the Kothapally watershed, Southern India, Hydrological Processes, 26, 387-404, 2012.

15 Gosain, A. K., Shrestha, A. B. and Rao, S.: Modelling climate change impact on the hydrology of the Eastern Himalayas, International Centre for Integrated Mountain Development (ICIMOD), Kathmandu, Nepal, available at: http://lib.icimod.org/record/8054/files/attachment_699.pdf, 2010.

Government of India: Cauvery basin report, Central Water Commission and National Remote Sensing Centre, New Delhi, available at: https://india-wris.nrsc.gov.in/Publications/BasinReports/Cauvery\%20Basin.pdf, 2014.

20 James, A. J., Kumar, M. D., Batchelor, J., Batchelor, C., Bassi, N., Choudhary, J., Gandhi, D., Syme, G., Milne, G. \& Kumar, P.: Catchment assessment and planning for watershed management, Volume 1- Main Report, World Bank, Washington DC, USA, available at: https://www.profor.info/sites/profor.info/files/Volu me\% 20IMain\%20Report\%20Catchment\%20Assessment\%20and\%20Planning\%20for\%20Watershed\%20Management 0.pdf, 2015.

Jamwal, P., Zuhail, T. M., Urs, P. R., Srinivasan, V. and Lele, S.: Contribution of sewage treat ment to pollution abatement of 25 urban streams, Current Science, 108, 677-685, 2015.

Kumar, M. D.: Managing Water in River Basins: Hydrology, Economics, and Institutions, Oxford University Press, New Delhi, India, 2010.

Kumar, M. D. and Singh, O. P.: (2001). Defining option boundaries: Physical options for groundwater management in Sabarmati river basin, INREM Foundation, Gujarat, India, available at:

30 https://www.researchgate.net/publication/313314634 Defining Option Boundaries Physical Choices for Integrated Wate r Management in Sabarmati River Basin, 2001. 
Hydrol. Earth Syst. Sci. Discuss., https://doi.org/10.5194/hess-2018-187

Manuscript under review for journal Hydrol. Earth Syst. Sci.

Discussion started: 15 May 2018

(c) Author(s) 2018. CC BY 4.0 License.

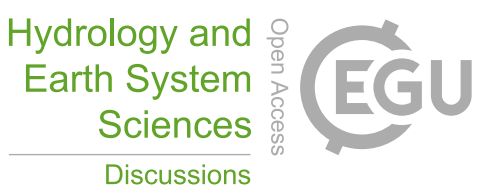

(c) (1)

Kumar, M. D., Ghosh, S., Singh, O. P., Ranade, R. and Ravindranath, R.: Changes in groundwater ecology and its implication for surface flows: Studies from Narmada river basin, Madhya Pradesh, Water Policy Research Highlight, IWMI-

Tata Water Policy Programme, Gujarat, India, available at: http://www.iwmi.cgiar.org/iwmitata/files/pdf/PM05/25 Highlight.pdf, 2005.

5 Penny, G., Srinivasan, V., Dronova, I., Lele, S. and Thompson, S.: Spatial characterization of long-term hydrological change in the Arkavathy watershed adjacent to Bangalore, India, Hydrology and Earth System Sciences, 22, 595-610, 2018.

Srinivasan, V., Thompson, S., Madhyastha, K., Penny, G., Jeremiah, K. \& Lele, S.: Why is the Arkavathy River drying? A multiple-hypothesis approach in a data-scarce region, Hydrology and Earth System Sciences, 19, 1905-1917, 2015. 
Hydrol. Earth Syst. Sci. Discuss., https://doi.org/10.5194/hess-2018-187

Manuscript under review for journal Hydrol. Earth Syst. Sci.

Discussion started: 15 May 2018

Table 1: Summary on Data Digitised by State Water Data Centre for various River Basins in Karnataka

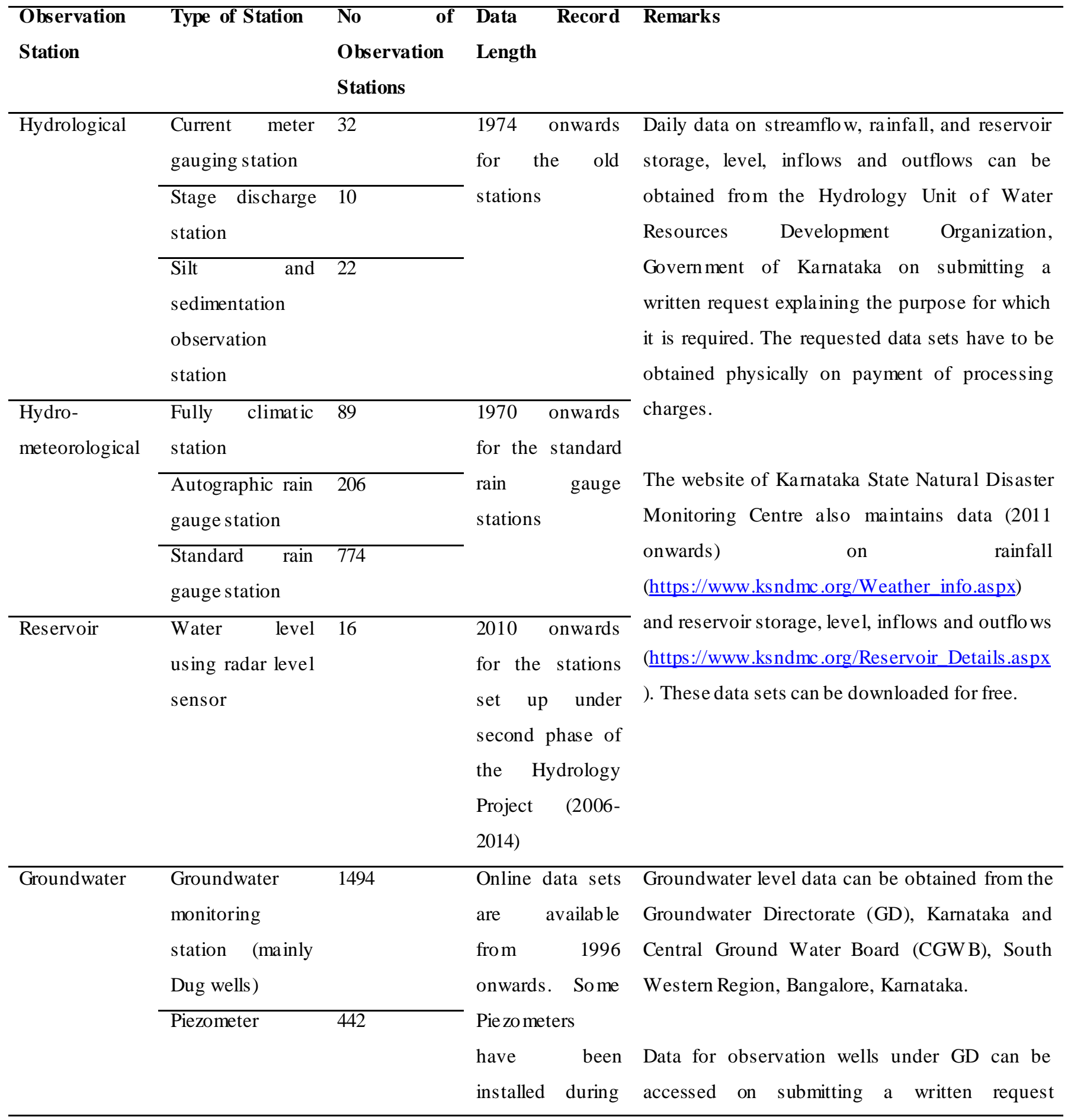


Hydrol. Earth Syst. Sci. Discuss., https://doi.org/10.5194/hess-2018-187

Manuscript under review for journal Hydrol. Earth Syst. Sci.

Discussion started: 15 May 2018

(c) Author(s) 2018. CC BY 4.0 License.

Data for observation wells under CGWB is available online and can be downloaded for free from the website of India-WRIS (http://www.india-

wris.nrsc.gov.in/GW LevelApp.html?UType=R2

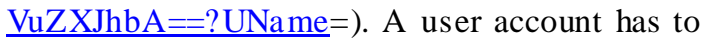
be created for downloading the data.

(Source: http://waterres ources.kar.nic.in/wrdo.htm, http://www.india-wris.nrsc.gov.in/, and Central Ground Water Board, 2016) 
Hydrol. Earth Syst. Sci. Discuss., https://doi.org/10.5194/hess-2018-187

Manuscript under review for journal Hydrol. Earth Syst. Sci.

Discussion started: 15 May 2018

(c) Author(s) 2018. CC BY 4.0 License.

\section{Hydrology and \\ Earth System \\ Sciences \\ Discussions}

(c) (1)

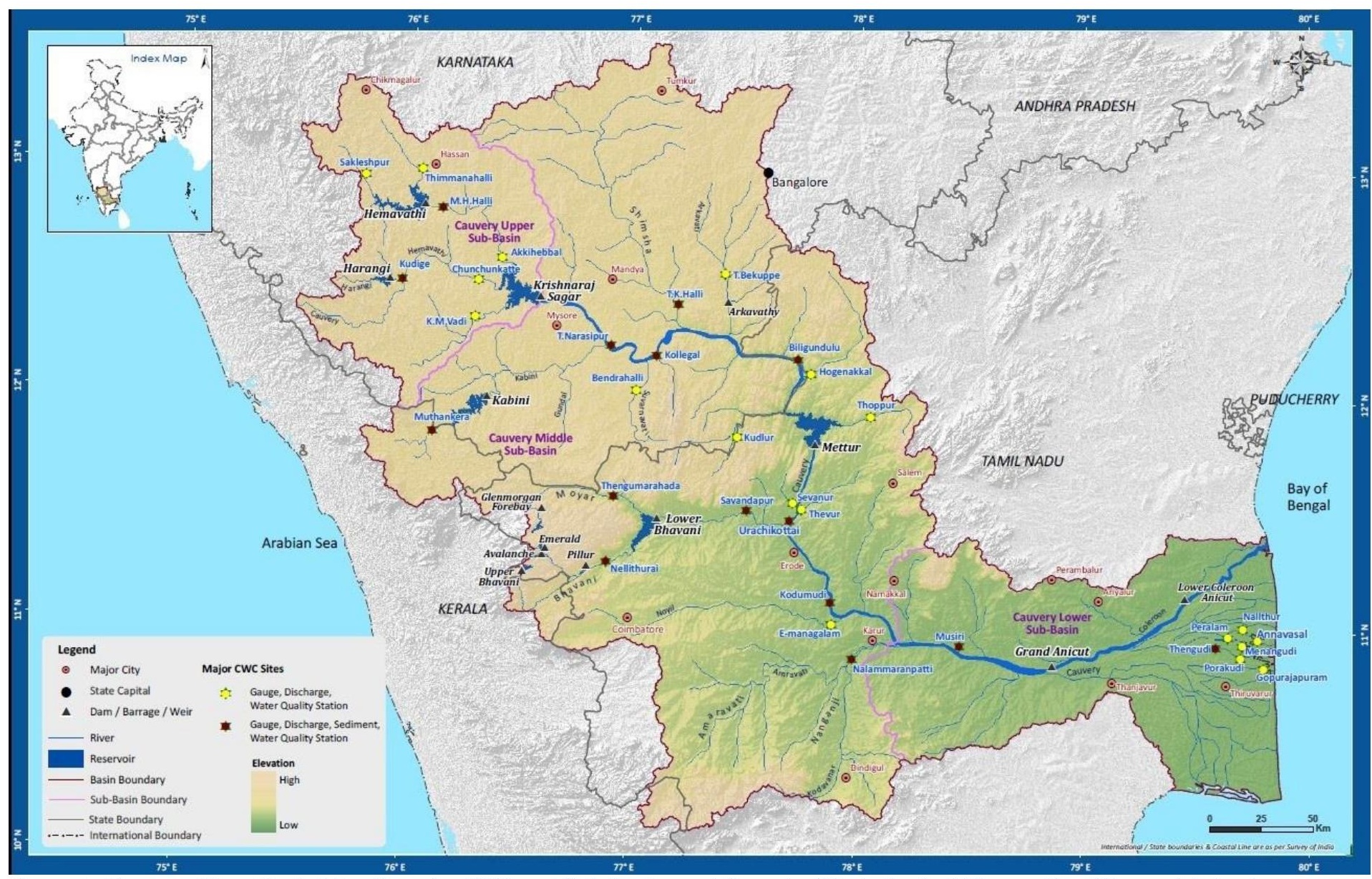

Figure 1: Cauvery River Basin Map Showing Different Sub-basins and Spread of Hydrological Observation Sites maintained by CWC

5 (Source: Government of India, 2014) 
Hydrol. Earth Syst. Sci. Discuss., https://doi.org/10.5194/hess-2018-187

Manuscript under review for journal Hydrol. Earth Syst. Sci.

Discussion started: 15 May 2018

(c) Author(s) 2018. CC BY 4.0 License.

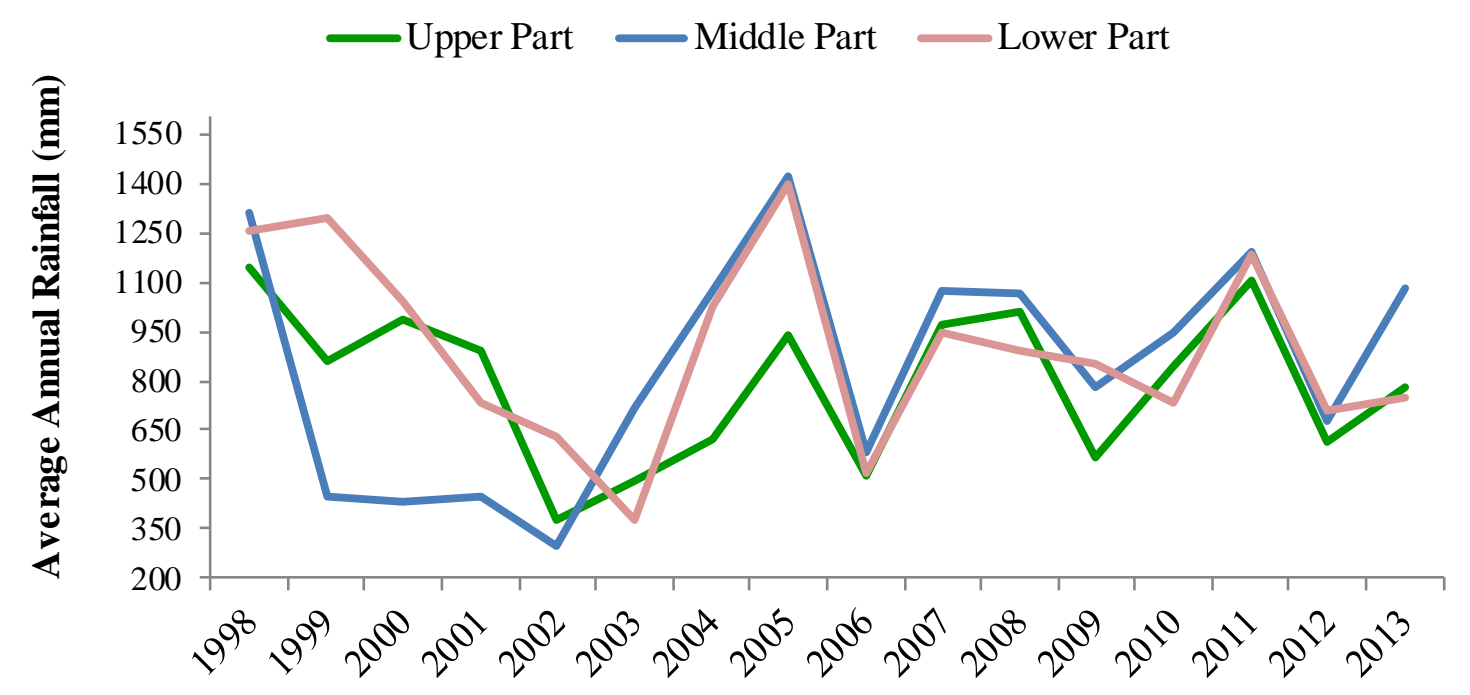

Figure 2: Rainfall Variation in Arkavathy Watershed.

(Source: Based on IMD gridded rainfall data sets)

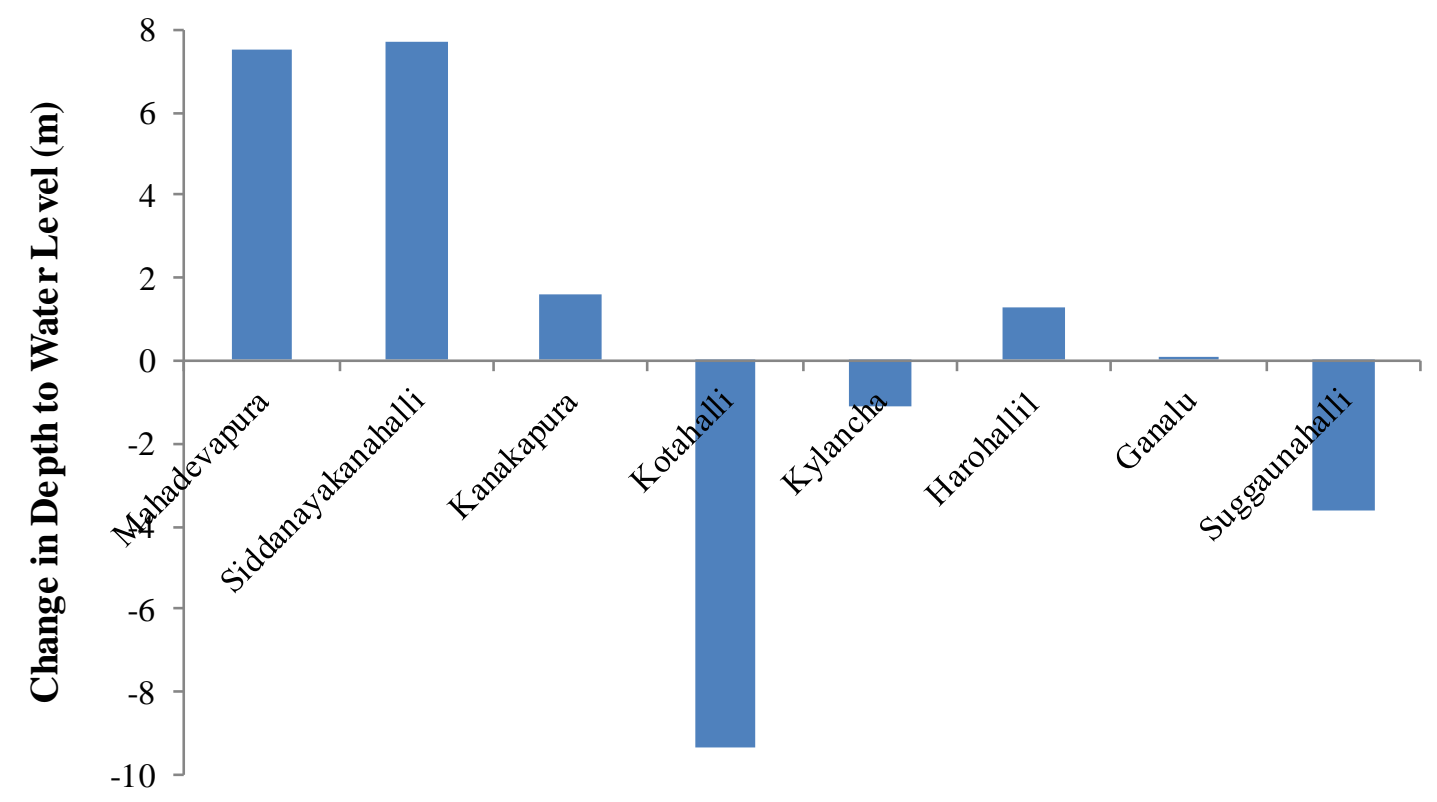

Figure 3: Long Term Change in Groundwater Levels in Arkavathy Watershed: 1996-2015. 
Hydrol. Earth Syst. Sci. Discuss., https://doi.org/10.5194/hess-2018-187

Manuscript under review for journal Hydrol. Earth Syst. Sci.

Discussion started: 15 May 2018

(c) Author(s) 2018. CC BY 4.0 License.

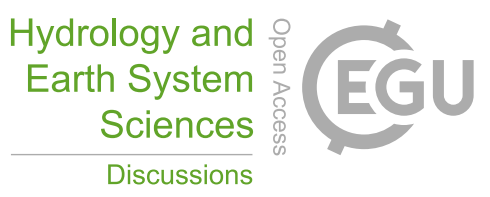

(c) (1)

(Source: Based on CGWB groundwater observation wells data sets) 